\title{
Anti-Ma and anti-Ta associated paraneoplastic neurological syndromes: 22 newly diagnosed patients and review of previous cases
}

\author{
L A Hoffmann, ${ }^{1} \mathrm{~S}$ Jarius, ${ }^{1,5} \mathrm{H}$ L Pellkofer, ${ }^{1} \mathrm{M}$ Schueller, ${ }^{1} \mathrm{M}$ Krumbholz, ${ }^{1} \mathrm{~F}$ Koenig, ${ }^{2}$ \\ W Johannis, ${ }^{3} \mathrm{C}$ la Fougere, ${ }^{4} \mathrm{~T}$ Newman, ${ }^{5} \mathrm{~A}$ Vincent, ${ }^{5} \mathrm{R}$ Voltz ${ }^{1,6}$
}

See Editorial Commentary, p 742

- The appendix is published online only at http://jnnp.bmj. com/content/vol79/issue7

${ }^{1}$ Institute of Clinical

Neuroimmunology, LudwigMaximilians-University, Munich, Germany; ${ }^{2}$ Institute of

Neuropathology, University of Goettingen, Germany:

${ }^{3}$ Department of Laboratory Medicine, University Hospital, Cologne, Germany; ${ }^{4}$ Department of Nuclear Medicine, LudwigsMaximilians-University, Munich, Germany; ${ }^{5}$ Weatherall Institute of Molecular Medicine, John Radcliffe Hospital, University of Oxford, UK; ${ }^{6}$ Department of Palliative Medicine, University Hospital, Cologne, Germany

\section{Correspondence to:}

Professor R Voltz, Department of Palliative Medicine, University of Cologne, Kerpener Str 62, 50924 Köln, Germany; raymond.voltz@ uk-koeln.de

Received 22 February 2007 Revised 1 November 2007 Accepted 5 January 2008 Published Online First 25 January 2008

\begin{abstract}
Background: Paraneoplastic neurological syndromes (PNS) are indirect remote effects of cancer on the nervous system, often associated with the presence of specific serum antibodies. The most recently described PNS defining reactivity is anti-Ma/anti-Ta. Here we present 22 newly diagnosed patients with anti-Ma or antiTa reactivity, refine the associated clinical picture and review all published patients to date.
\end{abstract}

Patients and methods: Patients were identified by testing for PNMA1 and PNMA2 antibodies by western blotting and indirect immunofluorescence. Clinical data were obtained either by referral of the patient or from the referring physicians.

Results: Analysis of 22 new patients (14 anti-Ma, eight anti-Ta) confirmed that anti-Ta are usually found in young men with limbic encephalitis and testicular germ cell tumours who stabilise neurologically with long term survival after tumour treatment. Patients with anti-Ma were of either sex, middle-aged, presented with a range of tumours and neurological symptoms and had a limited response to treatment. Furthermore, we expanded the range of associated clinical features: (1) the peripheral nervous system may be involved; (2) an overlap with anti$\mathrm{Hu}$ is possible; and (3) testicular tumour manifestation can be extragonadal or detectable only at orchiectomy. Conclusion: Refining and expanding the range of anti$\mathrm{Ma} /$ anti-Ta associated neurological presentations and tumours clearly demonstrated that the distinction between anti-Ma and anti-Ta associated PNS is of high clinical relevance.

Paraneoplastic neurological syndromes (PNS) are indirect remote effects of cancer on the nervous system. ${ }^{12}$ A positive diagnosis of PNS has become possible in many cases by identification of highly specific antibodies in patients' sera, ${ }^{12}$ and new diagnostic criteria have been defined. ${ }^{3}$ Six antibody reactivities are widely recognised and, if present, indicate a "definite" PNS. ${ }^{3}$ Therefore, accurate antibody testing and description of the associated clinical syndromes is of high clinical relevance.

In reference to the consensus paper by Graus et al in $2004,{ }^{3}$ anti-Ma/anti-Ta reactivity is the most recently described PNS defining antibody of the six specific antibodies described, which define a neurological syndrome as definite. ${ }^{3-5}$ Anti-Ta sera recognise an onconeuronal protein called PNMA2, and anti-Ma sera recognise PNMA2 and another protein, PNMA1. ${ }^{4-7}$ To date, there have been reports on approximately 50 patients with anti$\mathrm{Ma}$ or anti-Ta reactivity of whom enough information is given in the papers to differentiate 12 patients with anti-Ma (reacting with PNMA1 and PNMA2) and 28 patients with anti-Ta (reacting with PNMA2 only). ${ }^{4-17}$ Here we describe a further 22 patients with anti-Ma or anti-Ta associated PNS and comprehensively review all of the cases that have been reported in the literature. ${ }^{4-17}$

\section{PATIENTS AND METHODS}

Patients were identified in serial routine diagnostic testing for antineuronal antibodies in Munich and Oxford between December 1999 and March 2005. In Munich, sera were tested using western blot analysis with semi-purified recombinant human PNMA1 and PNMA2 protein, as described previously. ${ }^{45}$ Patients' sera, in parallel with normal control sera, were diluted 1:500, 1:2000 and 1:5000 in blocking buffer. As secondary antibodies, goat anti-rabbit IgG-HRP (Santa Cruz, California, USA) and anti-human IgG peroxidase conjugate (SigmaAldrich, Steinheim, Germany) were used. Antibody binding was detected using enhanced chemiluminescent detection reagents ${ }^{18}$ (Amersham Biosciences, New Jersey, USA). In addition, indirect immunofluorescence assays on monkey cerebellum/cerebrum and on mouse stomach slides were performed according to the manufacturer's instructions (The Binding Site Ltd, Birmingham, UK). In Oxford, sera were first screened by indirect immunohistochemistry, as described previously, ${ }^{4}{ }^{5}$ and sera with reactivity characteristic of anti-Ma/ $\mathrm{Ta}$ were retested and confirmed by binding on western blots in Munich.

For clinical information, when possible patients were referred to the Munich centre and attended our outpatient or inpatient department (6/22 personally seen by LAH and RV). In other cases, and in Oxford, clinical data were obtained from the referring physicians, and the clinical management discussed with them. Patient No 17 has been reported previously. ${ }^{14}$ Clinical outcome was rated according to the modified Rankin Scale.

For review of all published cases, we performed a Medline database search using the search keys "Ma, Ta, Ma1, Ma2, paraneoplastic, paraneoplastic neurological syndromes and limbic encephalitis". Furthermore, we included related links and references of the respective articles.

For statistical analysis, comparison of age distribution (Ma vs Ta positive patients) was done by the Mann-Whitney rank sum test. Frequencies of categorical data were analysed by Fisher exact tests. Data were analysed in an explorative way 


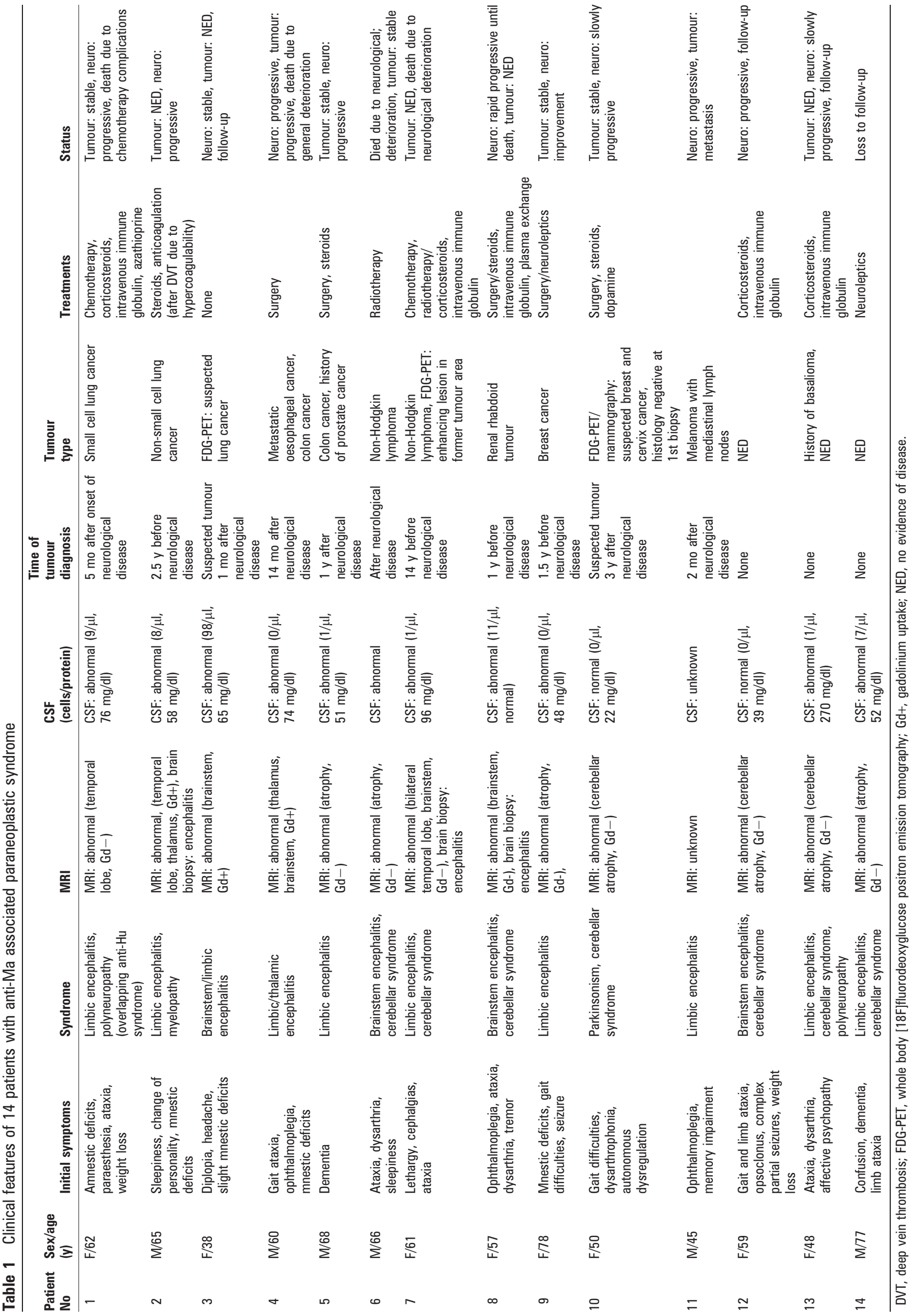


without adjustment for multiple testing. All calculations were done using SigmaStat V 3.0.1 (SPSS GmbH Software, Munich, Germany).

\section{RESULTS}

Patients are discussed below in relation to their antibody positivity. Six individual cases are described in detail in the appendix (available online). All patients fitted the criteria for definite paraneoplastic syndromes, as defined by Graus and colleagues. ${ }^{3}$

\section{Anti-Ma positive patients}

Fourteen anti-Ma (reacting with both PNMA1 and PNMA2) patients were identified (eight females, six males). The patients are described in table 1 and compared with the anti-Ta positive patients in table 2 .

Most patients had or developed symptoms of limbic encephalitis $(10 / 14)$, brainstem or cerebellar encephalitis (8/14), polyneuropathy $(2 / 14)$, extrapyramidal involvement $(1 / 14)$ or a combination thereof (table 1). Neuroimaging showed abnormalities in all 13 patients in whom cerebral MRI was performed (atrophic changes $7 / 13$, localised signal changes $6 / 13$, of those three with gadolinium enhancement). Two examples are given in figs 1 and 2 . CSF revealed abnormal results in 11/13 patients (in one case, no lumber puncture was performed), with elevated protein (9/11), pleocytosis (5/11) and positive oligoclonal bands (3/11).

A brain biopsy was performed in four cases. In patient No 2 , a biopsy of a left-sided mesial-temporal lesion showed diffuse parenchymal and perivascular inflammatory lymphocytic infiltrates predominantly of $\mathrm{T}$ cells (CD3 and CD8), but also of $\mathrm{B}$ cells (CD20 and CD79a) and a distinct reactive astrogliosis (see fig 3). Molecular genetic studies supported an inflammatory condition with a polyclonal pattern of the $\mathrm{IgH}$ rearrangements.

In patient No 7, a biopsy of the right-sided mesial-basal temporal lobe showed a subacute encephalitic picture with lymphocytic and monocytic perivascular cuffs, phagocytosis of nerve cells, extensive proliferation of microglia and reactive astrocytosis. In patient No 8, a brainstem biopsy revealed an inflammatory process with a predominant CD3 and CD68 positive infiltrate, extensive axonal degeneration and reactive astrocytosis.

\section{Associated tumours}

A tumour was histologically identified in nine patients $(9 / 14$, $64 \%)$. These included lung, gastrointestinal tract, non-Hodgkin lymphoma, breast, renal and melanoma with mediastinal lymph nodes. Among those without an identified tumour, patient No 7 had a history of a non-Hodgkin's disease (mucosa associated lymphatic tissue lymphoma in the terminal ileum 14 years ago) with [18F]fluorodeoxyglucose positron emission tomography (FDG-PET) investigation showing hypermetabolism in the area of the former tumour. Colonoscopy and CT of the abdomen did not detect any signs of tumour recurrence at the time of the diagnostic procedures. The patient deteriorated rapidly with additional signs of hypothalamic involvement (severe hyponatraemia and hypothermia) and died of

Table 2 Clinical features of eight patients with anti-Ta associated paraneoplastic syndrome

\begin{tabular}{|c|c|c|c|c|c|c|c|c|c|}
\hline $\begin{array}{l}\text { Patient } \\
\text { No }\end{array}$ & $\begin{array}{l}\text { Sex/age } \\
\text { (y) }\end{array}$ & Initial symptoms & Syndrome & MRI & $\begin{array}{l}\text { CSF } \\
\text { (cells/protein) }\end{array}$ & $\begin{array}{l}\text { Time of } \\
\text { tumour } \\
\text { diagnosis }\end{array}$ & $\begin{array}{l}\text { Tumour } \\
\text { type }\end{array}$ & Treatments & Status \\
\hline 15 & $\mathrm{M} / 66$ & $\begin{array}{l}\text { Mnestic deficit, } \\
\text { aphasia }\end{array}$ & $\begin{array}{l}\text { Limbic } \\
\text { encephalitis }\end{array}$ & $\begin{array}{l}\text { MRI: abnormal } \\
\text { (atrophy, Gd-), } \\
\text { brain biopsy: } \\
\text { encephalitis }\end{array}$ & $\begin{array}{l}\text { CSF: abnormal } \\
(0 / \mu \mathrm{l}, 81 \mathrm{mg} / \\
\mathrm{dl}))\end{array}$ & $\begin{array}{l}3 \text { mo after } \\
\text { neurological } \\
\text { disease at } \\
\text { orchiectomy }\end{array}$ & $\begin{array}{l}\text { Testicular } \\
\text { germ cell } \\
\text { tumour }\end{array}$ & $\begin{array}{l}\text { Orchiectomy/ } \\
\text { steroids/plasma } \\
\text { exchange }\end{array}$ & $\begin{array}{l}\text { Died due to } \\
\text { neurological } \\
\text { deterioration, } \\
\text { tumour: NED }\end{array}$ \\
\hline 16 & $\mathrm{M} / 33$ & $\begin{array}{l}\text { Ophthalmoplegia, } \\
\text { dysarthrophonia, } \\
\text { depressive mood }\end{array}$ & $\begin{array}{l}\text { Limbic } \\
\text { encephalitis, } \\
\text { cerebellar } \\
\text { syndrome }\end{array}$ & $\begin{array}{l}\text { MRI: abnormal } \\
\text { (basal ganglia, } \\
\mathrm{Gd}-\text { ) }\end{array}$ & CSF: not done & $\begin{array}{l}1.5 \text { y after } \\
\text { neurological } \\
\text { disease }\end{array}$ & $\begin{array}{l}\text { Extragonadal } \\
\text { germ cell } \\
\text { tumour }\end{array}$ & $\begin{array}{l}\text { Surgery, } \\
\text { chemotherapy/ } \\
\text { steroids }\end{array}$ & $\begin{array}{l}\text { Tumour: NED at } \\
4 \mathrm{y} \text {, neuro: partial } \\
\text { improvement }\end{array}$ \\
\hline 17 & $\mathrm{M} / 38$ & $\begin{array}{l}\text { Obsessive } \\
\text { compulsive } \\
\text { symptoms }\end{array}$ & $\begin{array}{l}\text { Limbic } \\
\text { encephalitis }\end{array}$ & $\begin{array}{l}\text { MRI: abnormal } \\
\text { (hippocampus, } \\
\text { Gd-) }\end{array}$ & $\begin{array}{l}\text { CSF: abnormal } \\
\text { (2/ } \mu \mathrm{l}, 46 \mathrm{mg} / \mathrm{dl}, \\
\text { Ma1 positive) }\end{array}$ & $\begin{array}{l}6 \text { mo after } \\
\text { neurological } \\
\text { disease }\end{array}$ & $\begin{array}{l}\text { Testicular } \\
\text { germ cell } \\
\text { tumour }\end{array}$ & $\begin{array}{l}\text { Orchiectomy, surgery } \\
\text { of metastases, } \\
\text { chemotherapy/ } \\
\text { steroids, intravenous } \\
\text { immunoglobulin, } \\
\text { anticonvulsants }\end{array}$ & $\begin{array}{l}\text { Tumour: NED } 1 \mathrm{y} \text {, } \\
\text { neuro: stable }\end{array}$ \\
\hline 18 & $\mathrm{M} / 21$ & $\begin{array}{l}\text { Epileptic seizure, } \\
\text { amnestic } \\
\text { syndrome }\end{array}$ & $\begin{array}{l}\text { Limbic } \\
\text { encephalitis }\end{array}$ & $\begin{array}{l}\text { MRI: abnormal } \\
\text { (hippocampus, } \\
\text { hypothalamus, Gd?) }\end{array}$ & $\begin{array}{l}\text { CSF: abnormal } \\
\text { (32/ } \mu \mathrm{l}, 65 \mathrm{mg} / \\
\text { dl) }\end{array}$ & $\begin{array}{l}1 \text { mo before } \\
\text { neurological } \\
\text { disease }\end{array}$ & $\begin{array}{l}\text { Testicular } \\
\text { teratoma }\end{array}$ & $\begin{array}{l}\text { Orchiectomy, } \\
\text { anticonvulsants, } \\
\text { intravenous } \\
\text { immunoglobulin }\end{array}$ & $\begin{array}{l}\text { Tumour: NED, } \\
\text { neuro: stable }\end{array}$ \\
\hline 19 & $\mathrm{M} / 53$ & $\begin{array}{l}\text { Hypaesthesia, } \\
\text { paraesthesia, gait } \\
\text { difficulties, } \\
\text { autonomous } \\
\text { dysregulation }\end{array}$ & Polyneuropathy & $\begin{array}{l}\text { MRI: normal, nerve } \\
\text { biopsy: chronic } \\
\text { inflammatory PNP }\end{array}$ & $\begin{array}{l}\text { CSF: abnormal } \\
\text { (normal, } 61 \mathrm{mg} / \\
\text { dl) }\end{array}$ & $\begin{array}{l}14 \text { y before } \\
\text { neurological } \\
\text { disease }\end{array}$ & $\begin{array}{l}\text { Testicular } \\
\text { germ cell } \\
\text { tumour }\end{array}$ & $\begin{array}{l}\text { Orchiectomy, } \\
\text { radiotherapy, } \\
\text { chemotherapy, } \\
\text { steroids }\end{array}$ & $\begin{array}{l}\text { Tumour: NED, } \\
\text { neuro: slowly } \\
\text { progressive, follow- } \\
\text { up }\end{array}$ \\
\hline 20 & $\mathrm{M} / 37$ & $\begin{array}{l}\text { Temporal lobe } \\
\text { epilepsy with } \\
\text { aura }\end{array}$ & $\begin{array}{l}\text { Limbic } \\
\text { encephalitis }\end{array}$ & $\begin{array}{l}\text { MRI: abnormal } \\
\text { (temporal lobe, } \\
\text { Gd+), brain biopsy: } \\
\text { encephalitis }\end{array}$ & $\begin{array}{l}\text { CSF: abnormal } \\
(9 / \mu \mathrm{l}, 35 \mathrm{mg} / \mathrm{dl})\end{array}$ & $\begin{array}{l}\text { Suspected } \\
\text { tumour } 6 \text { mo } \\
\text { before } \\
\text { neurological } \\
\text { disease }\end{array}$ & $\begin{array}{l}\text { Reversible } \\
\text { testicular } \\
\text { swelling }\end{array}$ & $\begin{array}{l}\text { Steroids, } \\
\text { anticonvulsants }\end{array}$ & $\begin{array}{l}\text { Tumour: NED, } \\
\text { neuro: partial } \\
\text { improvement }\end{array}$ \\
\hline 21 & $\mathrm{M} / 70$ & Gait difficulties & $\begin{array}{l}\text { Upper + lower } \\
\text { motor neuron } \\
\text { syndrome }\end{array}$ & MRI: not performed & $\begin{array}{l}\text { CSF: abnormal } \\
(0 / \mu \mathrm{l}, 52 \mathrm{mg} / \mathrm{dl})\end{array}$ & None & None & None & $\begin{array}{l}\text { Neuro: stable, } \\
\text { follow-up }\end{array}$ \\
\hline 22 & $\mathrm{M} / 74$ & $\begin{array}{l}\text { Dementia, } \\
\text { sleepiness }\end{array}$ & $\begin{array}{l}\text { Limbic } \\
\text { encephalitis }\end{array}$ & $\begin{array}{l}\text { MRI: abnormal } \\
\text { (atrophy, Gd-) }\end{array}$ & $\begin{array}{l}\text { CSF: abnormal } \\
(7 / \mu \mathrm{l}, 52 \mathrm{mg} / \mathrm{dl})\end{array}$ & None & None & None & $\begin{array}{l}\text { Died due to } \\
\text { neurological } \\
\text { deterioration, } \\
\text { tumour: NED }\end{array}$ \\
\hline
\end{tabular}




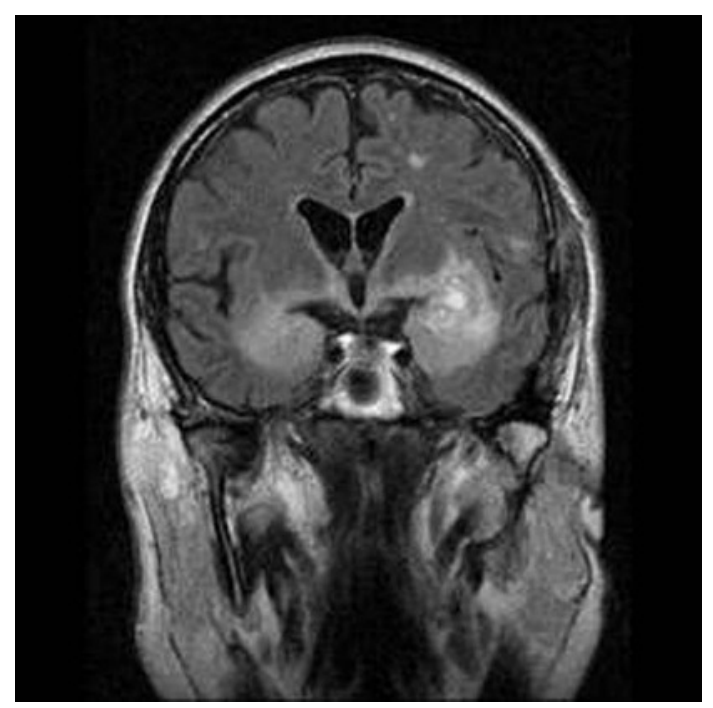

Figure 1 Patient No 2 with anti-Ma associated paraneoplastic limbic encephalitis. Fluid attenuated inversion recovery sequence of MRI showing bilateral mesial-temporal lobe signal change. See fig 3 for biopsy results.

pneumonia with no autopsy performed. In three patients $(3 / 14$, $21 \%$ ), there was suspicion of a tumour but no definite diagnosis during the average follow-up period of 2 years. In patient No 3 , a hypermetabolic area highly suspicious for lung cancer was not reproducible 3 months later. In patient No 10, mammography and FDG-PET indicated neoplastic lesions in the breast and uterus, but biopsies could not confirm the suspicion. Follow-up 3 months later still showed a minimal uptaking lesion in the biopsy area of the breast. The patient is currently closely being followed. In two patients $(2 / 14,14 \%)$, there has not been evidence of a tumour to date; in patient Nos 12 and 13, serial tumour screenings, including FDG-PET, have so far been negative. Patient No 14 was lost to follow-up. An example of a suspicious FDG-PET-CT lesion is shown in fig 4.

In four patients the tumour diagnosis was before (mean 4.75 years, median 2 years, range $1-14$ years), and in five after the onset of neurological symptoms (mean 8 months, median 13 months, range $2-14$ months). The mean time of close followup for those patients who are alive without evidence of tumour is 4 years (median 23 months, range 12 months to 10 years).

\section{Treatment and outcome}

In $11 / 13$ patients ( $85 \%$, one lost to follow-up), the neurological disease was progressive. Immunotherapy (steroids, plasma exchange, intravenous immunoglobulins) had no effect or achieved only very little or temporary stabilisation of the neurological syndrome. Patient No 9 improved neurologically after surgery of her breast cancer. In one case (patient No 3) the neurological disease stabilised without any immune treatment and the suspicious pulmonal PET lesion has reversed. Tumour disease stabilised in seven patients and was progressive in two cases. Five patients have died (36\%), three as a result of neurological deterioration, one because of chemotherapy complications and one related to tumour cachexy and worsening of general condition.

\section{Anti-Ta positive patients}

Eight patients were positive for anti-Ta (anti-PNMA2 only) and all were men (table 2$)$. Six patients $(6 / 8,75 \%)$ presented with a limbic syndrome, one with predominant obsessive-compulsive

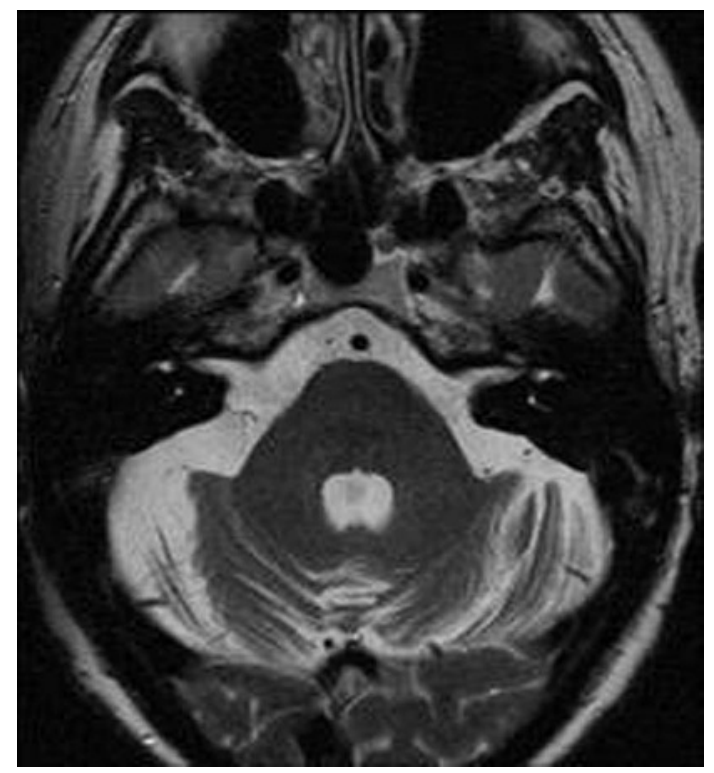

Figure 2 Patient No 13 with anti-Ma associated paraneoplastic cerebellar syndrome and limbic encephalitis. MRI showing cerebellar atrophy, predominantly in both hemispheres.

symptoms, as reported previously. ${ }^{14}$ One of those showed additional brainstem/cerebellar symptoms. One patient developed a polyneuropathy, another patient signs of upper and lower motor neuron involvement. Cerebral MRI was performed in seven patients, with an abnormal result in 6/7-namely, signal changes in 5/7 and atrophic changes in 1/7. CSF analysis was abnormal in $7 / 8$ patients (in one case, no lumbar puncture was performed) with elevated protein $(6 / 7)$, pleocytosis $(3 / 7)$ and positive oligoclonal bands (3/7).

A brain biopsy was performed in two patients. Patient No 15 showed reactive gliosis, activated microglia and a slightly increased cell density. Patient No 20 had perivascular lymphocytic infiltrates, predominantly of CD45 positive $\mathrm{T}$ cells and polyclonal plasma cells confirming the diagnosis of an encephalitis rather than the initially suspected primary CNS lymphoma.

\section{Associated tumours}

In $5 / 8(63 \%)$ cases, a germ cell tumour was identified during follow-up; one had extragonadal manifestations and one was diagnosed only at orchiectomy. In three of the five patients with a diagnosed tumour, the tumour was identified only after the onset of the neurological syndrome (mean time interval of 9 months (median 6), range 3-18 months). In two patients the tumour was diagnosed before the PNS evolved; one patient (patient No 18) developed PNS only 1 month after diagnosis of a testicular teratoma and the other patient (patient No 19) had a past history of testicular seminoma 14 years previously, and during 38 months of follow-up ultrasound examination of the testis detected a heterogeneous non-cystic structure. Open biopsy revealed macro- and microscopic unremarkable results. Orchiectomy was considered but was rejected because of the indolent clinical picture and the patient is under close followup. Patient No 20 recognised a testicular swelling 6 months before the onset of neurological symptoms, which resolved spontaneously before the planned biopsy. Close follow-up has not detected a testicular tumour until now. In patient No 21, no clinical signs of tumour were present during the 4 years of follow-up, but the patient refuses any further investigations as 

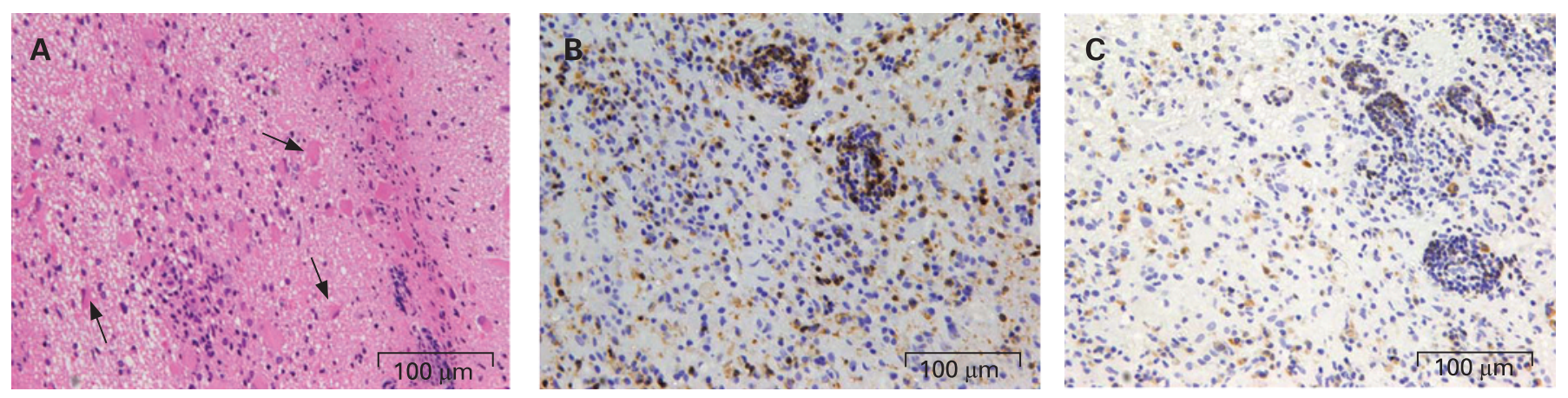

Figure 3 Patient No 2 with anti-Ma associated paraneoplastic limbic encephalitis. Brain biopsy. (A) Haematoxylin-eosin staining $(\times 200)$ demonstrates diffuse inflammatory lymphocytic infiltrates and reactive astrocytes (arrows). (B, C) Immunocytochemistry stainings ( $\times 200$ ) with avidinbiotin technique show brown labelled immunopositive cells. The perivascular and diffuse parenchymal lymphocytic infiltrates consist of CD3 positive $T$ cells (B) as well as C79a positive B cells (C).

his condition is stable. Patient No 22 deteriorated rapidly and died as a result of neurological complications without evidence of tumour, despite many investigations. A postmortem examination was not conducted.

\section{Treatment and outcome}

Two patients died as a result of neurological deterioration with no clinical evidence of tumour recurrence in one and no tumour diagnosis in the other (autopsy not performed). In the six patients who are still alive, tumour disease remains stable (4/6), whereas the neurological disease is either slowly progressive (1/6), stable (3/ $6)$ or has even partially improved $(2 / 6)$. Treatment of the paraneoplastic syndrome with steroids, plasma exchange or intravenous immune globulin led to neurological stabilisation in four cases. In two cases, neurological stabilisation occurred after curative surgery and additional chemotherapy of the germ cell tumour. One patient developed neurological symptoms after orchiectomy, and treatment with intravenous immune globulin accomplished stabilisation in a moderate condition. In one patient repetitive courses of high dose steroids resolved distinct unilateral limbic encephalitis, with residual hippocampal atrophy (fig 5).

\section{Differences between anti-Ta and anti-Ma associated PNS}

The data confirm the distinction between anti-Ma and anti-Ta associated paraneoplastic syndromes. Most relevant differences are found in sex, age, associated tumour types, neurological outcome and prognosis. Table 3 includes all previously published data and emphasises the clinical relevance of the distinction between anti-Ma and anti-Ta reactivities. Table 4 (see appendix online) summarises the patients according to antibody status.

\section{DISCUSSION}

We have presented a series of 22 newly diagnosed patients with anti-Ma or anti-Ta reactivity and reviewed all published patients to date. Our data confirm that patients with anti-Ta antibodies are usually men of younger age, present with limbic encephalitis and are likely to have a testicular germ cell tumour which responds well to treatment with stabilisation of the neurological syndrome and long term survival. ${ }^{4-7} 19$ In contrast, patients with anti-Ma antibodies can be of either sex, usually middle aged and suffer from a range of tumours and neurological presentations and do much less well following tumour treatment. ${ }^{6}$ Our observations extend the range of anti$\mathrm{Ma}$ and anti-Ta associated clinical characteristics. If in a man with anti-Ta no testicular germ cell tumour is found, it is important to look at extragonadal sites before considering orchiectomy. ${ }^{41920}$ Anti-Ma associated tumours are more heterogeneous, and a thorough and repeated tumour search is mandatory.

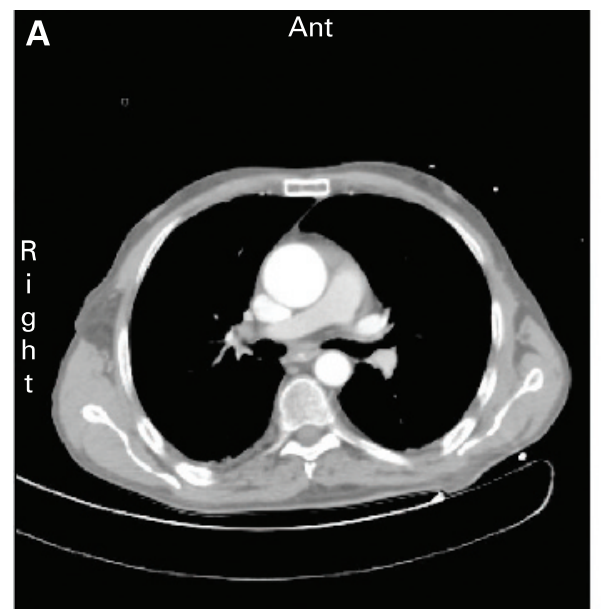

B

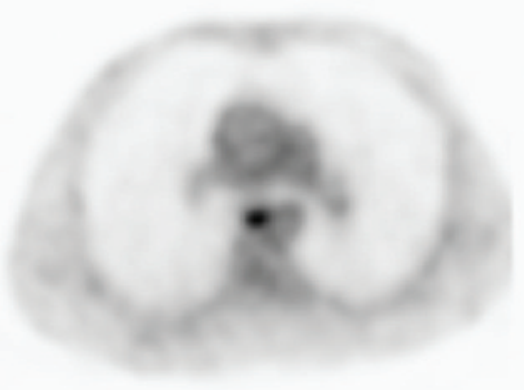

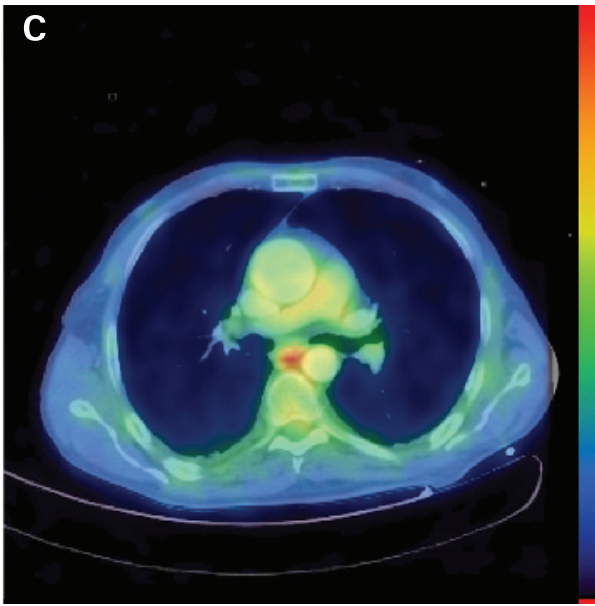

Figure 4 [18F]Fluorodeoxyglucose positron emission tomography (FDG-PET)/CT examination of patient No 4 with anti-Ma associated paraneoplastic limbic/thalamic encephalitis. Suspicious mediastinal FDG uptake (B) and inconclusive CT scan with slight wall thickening (A). Fused PET/CT image (C) locates the PET finding in the oesophagus. Biopsy proved metastatic oesophageal carcinoma. 


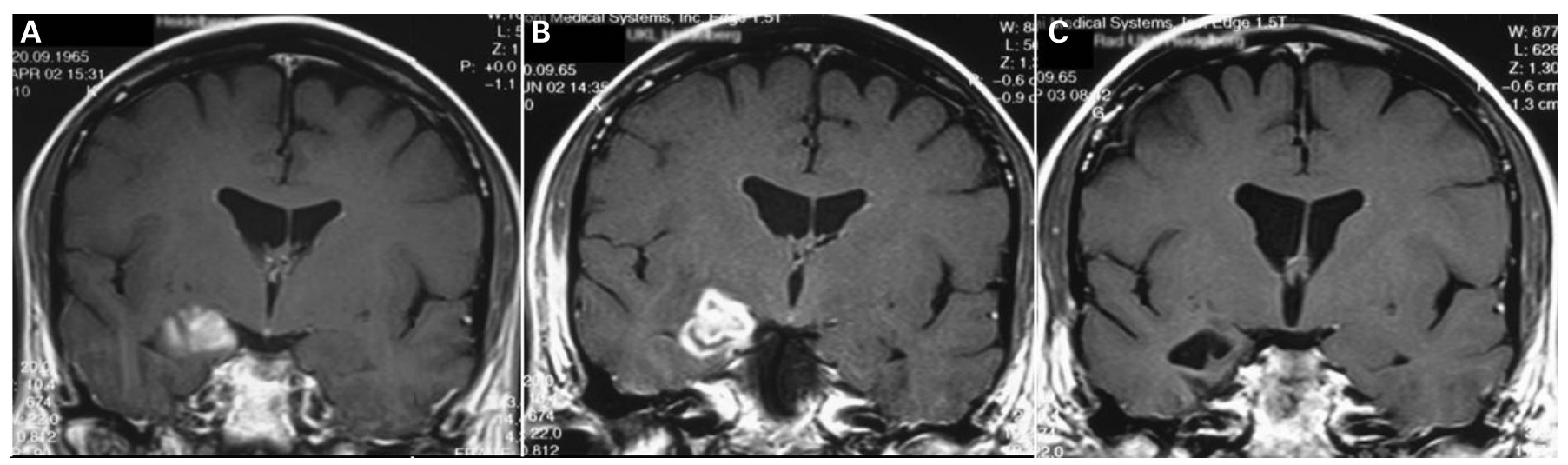

Figure 5 Patient No 20 with anti-Ta associated paraneoplastic limbic encephalitis. (A) Signal change in the right mesial temporal lobe. (B) Progressive lesion with gadolinium uptake 3 months later. (C) Resolution after repeated courses of high dose steroids with residual scar tissue.

Neurologically, the range of presentation of limbic affection may include an obsessive-compulsive behaviour or bithalamic involvement mimicking Wernicke encephalopathy. Furthermore, four of our patients suggest for the first time that involvement of the peripheral nervous system may also be associated with anti-Ma or anti-Ta reactivity. Involvement of the peripheral nervous system would also be theoretically conceivable as the PNMA proteins are also expressed in peripheral neurons. ${ }^{12}{ }^{21}$ In two patients with anti-Ta, affection of the peripheral nervous system occurred as an isolated neurological syndrome. In one patient the history of a seminoma and exclusion of other risk factors was very suggestive of a paraneoplastic aetiology of the polyneuropathy. The second patient showed clinical and electrophysiological involvement of the upper motor neurons in addition to predominant motor involvement of the peripheral nerves. This case and another published $\operatorname{case}^{17}$ demonstrate that, rarely, anti-Ta associated paraneoplastic disease should be included in the differential diagnosis of motor neuron disease. As described for other paraneoplastic syndromes, we also described the first patient with anti-Ma overlapping with another reactivity (anti-Hu with lung cancer). In this patient, the polyneuropathy may be ascribed to the anti-Hu syndrome.

Regarding the high clinical relevance, it is mandatory to check for cross reactivity and to measure paraneoplastic antibodies using two different methods as western blots using prokaryotic proteins might not detect all antibodies present in a polyclonal patient serum..$^{20}$

As demonstrated by several of our patients, tumour diagnosis may be difficult even in definite paraneoplastic syndromes, probably due to an effective immunological anti-tumour reaction. Whole body FDG-PET is an important addition to our diagnostic armentarium. ${ }^{22}$ Even with a positive FDG-PET, a

Table 3 Summary of all published patients with anti-Ma and anti-Ta associated paraneoplastic syndromes

\begin{tabular}{|c|c|c|c|}
\hline & Anti-Ma (anti-PNMA1 + PNMA2) & Anti-Ta (anti-PNMA2) & Statistical analysis \\
\hline $\mathrm{n}$ & 26 & 36 & \\
\hline $\operatorname{Sex}(F / M)$ & $16 / 10$ & $8 / 28$ & $p=0.004(F T)$ \\
\hline Age (y) (mean, median, range) & $61,61,38-82$ & $44,38,21-81$ & $p=0.001$ (RST) \\
\hline Neurological syndromes & $\begin{array}{l}\text { Cerebellar/brainstem syndrome } 77 \% \text {, } \\
\text { limbic encephalitis } 65 \% \text {, } \\
\text { polyneuropathy } 12 \% \text {, extrapyramidal } \\
\text { symptoms } 8 \% \text {, myelopathy } 4 \%\end{array}$ & $\begin{array}{l}\text { Limbic encephalitis } 64 \% \text {, } \\
\text { cerebellar/brainstem syndrome } \\
39 \% \text {, extrapyramidal symptoms } \\
6 \% \text {, polyneuropathy } 6 \% \text {, } \\
\text { myelopathy } 3 \%\end{array}$ & NS \\
\hline Tumour & $\begin{array}{l}\text { Tumour diagnosis in } 77 \% \text {, thereof lung } \\
25 \% \text {, GIT } 15 \% \text {, breast } 10 \% \text {, NHL } 10 \% \text {, } \\
\text { germ cell } 10 \% \text {, salivary gland } 10 \% \text {, } \\
\text { renal rhabdoid } 5 \% \text {, ovary } 5 \% \text {, } \\
\text { melanoma } 5 \% \text {, unknown primary } 5 \%\end{array}$ & $\begin{array}{l}\text { Tumour diagnosis in } 89 \% \text {, thereof } \\
\text { germ cell } 75 \% \text {, lung } 9 \% \text {, breast } \\
9 \% \text {, NHL } 3 \% \text {, ovary } 3 \%\end{array}$ & $\begin{array}{l}\text { Germ cell vs non- } \\
\text { germ cell } p<0.001 \\
\text { (FT) }\end{array}$ \\
\hline Time of diagnosis of tumour & $\begin{array}{l}\text { Paraneoplastic syndrome before } \\
\text { tumour diagnosis: } 66 \% \text {, range } 2- \\
14 \text { mo, paraneoplastic syndrome after } \\
\text { tumour diagnosis: } 39 \% \text {, range } 4 \text { mo- } \\
14 \text { y }\end{array}$ & $\begin{array}{l}\text { Paraneoplastic syndrome before } \\
\text { tumour diagnosis: } 82 \% \text {, range } 2- \\
36 \text { mo, paraneoplastic syndrome } \\
\text { after tumour diagnosis: } 18 \% \text {, } \\
\text { range } 1 \text { mo-14 y }\end{array}$ & NS \\
\hline CNS imaging & Abnormal $86 \%$ & Abnormal $82 \%$ & NS \\
\hline CSF & Abnormal $77 \%$ & Abnormal $81 \%$ & NS \\
\hline Outcome (neuro) & $\begin{array}{l}\text { Progression } 75 \% \text {, stabilisation } 19 \% \text {, } \\
\text { improvement } 5 \%\end{array}$ & $\begin{array}{l}\text { Progression } 31 \% \text {, stabilisation } \\
38 \% \text {, improvement } 31 \%\end{array}$ & $\begin{array}{l}\text { Progression vs non- } \\
\text { progression } \\
p=0.009(\mathrm{FT})\end{array}$ \\
\hline Outcome (tumour) & Stabilisation $82 \%$, progression $27 \%$ & Stabilisation 95\%, progression: $5 \%$ & NS \\
\hline Death & $\begin{array}{l}38 \% \text { (thereof } 70 \% \text { due to neurological } \\
\text { deterioration) }\end{array}$ & $\begin{array}{l}14 \% \text { (thereof } 80 \% \text { due to } \\
\text { neurological deterioration) }\end{array}$ & $\begin{array}{l}\text { Death vs alive } \\
p=0.021 \text { (FT) }\end{array}$ \\
\hline
\end{tabular}

FT, Fisher's exact test; GIT, gastrointestinal; NHL, non-Hodgkin lymphoma; RST, Mann-Whitney rank sum test. Classification of anti-Ma and anti-Ta according to the respective publication. In some studies testing of anti-PNMA1 was not performed and hence classification as anti-Ta or anti-Ma unclear. 
first attempt to diagnose the tumour histologically may be negative but can be positive at follow-up biopsy if the FDG-PET hypermetabolism persists, as demonstrated by one of our patients (patient No 4). An exception of clinical relevance is testis tissue, as the utilisation of FDG-PET is of limited sensitivity because of a hypermetabolic background. Furthermore, in anti-Ta, tumour diagnosis may only be obtained after radical orchiectomy, a procedure that must be weighed against the clinical background. ${ }^{19}$ Furthermore, tumour diagnosis may be delayed by several years, and close follow-up for patients with a paraneoplastic antibody is essential.

Tumour diagnosis may also be hampered by possible regression of the tumour by the underlying immune response. ${ }^{3}$ A probable clue to the immunopathology of paraneoplastic neurological disease (PND) is provided by patient No 20 with a reversible suspicious testicular swelling and patient No 15 with a diagnosis of intratubular germ cell neoplasia at orchiectomy only. As has been hypothesised before, ${ }^{21}{ }^{23}$ the immune response in the testis is triggered at an early stage or limited stage of cancer and an early and effective immunological response at the tumour site only becomes evident with the evolving neurological symptoms, but can accomplish tumour regression.

Not all of the patients were found to have tumours and some of the tumours were not those typically associated with Ma antibodies. However, all patients fitted the criteria for definite paraneoplastic syndromes, as defined by Graus and colleagues. ${ }^{3}$ One way to establish whether the associated tumours were immunological related to the syndromes would be to look for the Ma antigens in the tumours. Unfortunately, biopsy material was not available for any of the patients with atypical tumours.

Our neuropathology findings show that in the rare cases when a brain biopsy is performed for differential diagnosis a paraneoplastic encephalitis may be mistaken for a cerebral lymphoma. In this situation, re-evaluation of the histology by an expert neuropathologist is necessary. In addition to the presence of anti-Ma/anti-Ta antibodies, neuropathological analysis of the clonality of lymphoid cells may demonstrate polyclonality and points towards encephalitis. ${ }^{24-26}$

As has been reported previously, immunosuppressive treatment, such as intravenous immunoglobulin and plasma exchange, had little effect on outcome except in a few cases. This might be for two reasons: the neuronal damage takes place subacutely and is irreversible. Any immunosuppressive treatment must therefore take place as early as possible, probably best within the first month after onset of neurological symptoms. ${ }^{27}$ Furthermore, numerous pieces of evidence indicate that the tumour response and PND is characterised by the presence of PNS antigen specific $T$ cells, which are triggered by the capture of apoptotic tumour cells by tissue dendritic

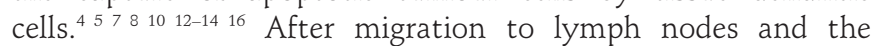
presence of CD4+ helper $\mathrm{T}$ cells, CD8+ killer $\mathrm{T}$ cells are activated. The above mentioned therapies work well in antibody mediated diseases, such as Lambert-Eaton myasthenic syndrome, but fail in PNS with an immune mechanism with predominantly cell mediated effects and probably less pathogenetic effect of the detected antibodies..$^{10} 1516$

In conclusion, anti-Ma and anti-Ta reactivities are of high clinical relevance in patients presenting with subacute brainstem or limbic symptoms and, if present, a thorough and persistent tumour search is warranted. Furthermore, it has to be kept in mind that every patient might present with unique clinical symptoms and that with the growing number of patients, new clinical presentations of tumour associations may be reported in the future.
Acknowledgements: The authors thank all cooperating physicians for providing the clinical data, especially B Wildemann, Department of Neurology, University Hospital Heidelberg, I Hart, The Walton Centre for Neurology and Neurosurgery, Liverpool and J Linn, Department of Neuroradiology, University Hospital Munich.

Funding: We thank the Deutsche Forschungsgemeinschaft (SFB 571, project D7), the Hermann und Lilly Schilling Stiftung and Sander Stiftung (Az 2002.121.1) for financial support.

Competing interests: None.

Ethics approval: Ethics approval was obtained.

\section{REFERENCES}

1. Darnell RB, Posner JB. Paraneoplastic syndromes involving the nervous system N Engl J Med 2003;349:1543-54.

2. Voltz R. Paraneoplastic neurological syndromes: an update on diagnosis, pathogenesis, and therapy. Lancet Neurol 2002;1:294-305.

3. Graus F, Delattre JY, Antoine JC, et al. Recommended diagnostic criteria for paraneoplastic neurological syndromes. J Neurol Neurosurg Psychiatry 2004;75:1135-40.

4. Dalmau J, Gultekin SH, Voltz R, et al. Ma1, a novel neuron- and testis-specific protein, is recognized by the serum of patients with paraneoplastic neurological disorders. Brain 1999;122:27-39.

5. Voltz R, Gultekin SH, Rosenfeld MR, et al. A serologic marker of paraneoplastic limbic and brain-stem encephalitis in patients with testicular cancer. $N$ Engl J Med 1999;340:1788-95.

6. Dalmau J, Graus F, Villarejo A, et al. Clinical analysis of anti-Ma2-associated encephalitis. Brain 2004;127:1831-44.

7. Rosenfeld MR, Eichen JG, Wade DF, et al. Molecular and clinical diversity in paraneoplastic immunity to Ma proteins. Ann Neurol 2001;50:339-48.

8. Overeem S, Dalmau J, Bataller L, et al. Hypocretin-1 CSF levels in anti-Ma2 associated encephalitis. Neurology 2004;62:138-40.

9. Blumenthal DT, Salzman KL, Digre KB, et al. Early pathologic findings and long-term improvement in anti-Ma2-associated encephalitis. Neurology 2006;67:146-9.

10. Barnett M, Prosser J, Sutton I, et al. Paraneoplastic brain stem encephalitis in a woman with anti-Ma2 antibody. J Neurol Neurosurg Psychiatry 2001; 70:222-5

11. Bennett JL, Galetta SL, Frohman LP, et al. Neuro-ophthalmologic manifestations of a paraneoplastic syndrome and testicular carcinoma. Neurology 1999;52:864-7.

12. Landolfi JC, Nadkarni M. Paraneoplastic limbic encephalitis and possible narcolepsy in a patient with testicular cancer: case study. Neurooncol 2003;5:214-16.

13. Sahashi K, Sakai K, Mano K, et al. Anti-Ma2 antibody related paraneoplastic limbic/ brain stem encephalitis associated with breast cancer expressing Ma1, Ma2, and Ma3 mRNAs. J Neurol Neurosurg Psychiatry 2003;74:1332-5.

14. Scheid R, Voltz R, Guthke T, et al. Neuropsychiatric findings in anti-Ma2-positive paraneoplastic limbic encephalitis. Neurology 2003;61:1159-61.

15. Sutton I, Winer J, Rowlands D, et al. Limbic encephalitis and antibodies to Ma2: a paraneoplastic presentation of breast cancer. J Neurol Neurosurg Psychiatry 2000;69:266-8.

16. Wong AM, Musallam S, Tomlinson RD, et al. Opsoclonus in three dimensions: oculographic, neuropathologic and modelling correlates. J Neurol Sci 2001;189:7181.

17. Waragai M, Chiba A, Uchibori A, et al. Anti-Ma2 associated paraneoplastic neurological syndrome presenting as encephalitis and progressive muscular atrophy. J Neurol Neurosurg Psychiatry 2006;77:111-13.

18. Schuller M, Jenne D, Voltz R. The human PNMA family: Novel neuronal proteins implicated in paraneoplastic neurological disease. J Neuroimmunol 2005;169:172-6.

19. Mathew RM, Vandenberghe R, Garcia-Merino A, et al. Orchiectomy for suspected microscopic tumor in patients with anti-Ma2-associated encephalitis. Neurology 2007:68:900-5

20. Voltz R. Can antibodies in serum predict the presence of microscopic tumors? Neurology 2007;20;68:887-8.

21. Darnell RB. Paraneoplastic neurologic disorders: windows into neuronal function and tumor immunity. Arch Neurol 2004;61:30-2.

22. Linke R, Schroeder M, Helmberger T, et al. Antibody-positive paraneoplastic neurologic syndromes: value of CT and PET for tumor diagnosis. Neurology 2004;63:282-6.

23. Albert ML, Darnell RB. Paraneoplastic neurological degenerations: keys to tumour immunity. Nat Rev Cancer 2004;4:36-44.

24. Voltz R, Dalmau J, Posner JB, et al. T-cell receptor analysis in anti-Hu associated paraneoplastic encephalomyelitis. Neurology 1998;51:1146-50.

25. Albert ML, Darnell JC, Bender A, et al. Tumor-specific killer cells in paraneoplastic cerebellar degeneration. Nat Med 1998;4:1321-4.

26. Jellinger KA, Paulus W. Primary central nervous system lymphomas-new pathological developments. J Neurooncol 1995;24:33-6.

27. Pellkofer $\mathbf{H}$, Schubart AS, Hoftberger R, et al. Modelling paraneoplastic CNS disease: T-cells specific for the onconeuronal antigen PNMA1 mediate autoimmune encephalomyelitis in the rat. Brain 2004;127:1822-30. 


\title{
JNP
}

\section{Anti-Ma and anti-Ta associated paraneoplastic neurological syndromes: 22 newly diagnosed patients and review of previous cases}

\author{
L A Hoffmann, S Jarius, H L Pellkofer, et al. \\ J Neurol Neurosurg Psychiatry 2008 79: 767-773 originally published \\ online January 25,2008 \\ doi: 10.1136/jnnp.2007.118588
}

Updated information and services can be found at:

http://jnnp.bmj.com/content/79/7/767.full.html

These include:
Data Supplement "web only appendix"
http://jnnp.bmj.com/content/suppl/2008/05/27/79.7.767.DC1.html
References This article cites 27 articles, 17 of which can be accessed free at: http://jnnp.bmj.com/content/79/7/767.full.html\#ref-list-1
Article cited in:
http://jnnp.bmj.com/content/79/7/767.full.html\#related-urls

Email alerting Receive free email alerts when new articles cite this article. Sign up in service the box at the top right corner of the online article.

Topic Articles on similar topics can be found in the following collections Collections

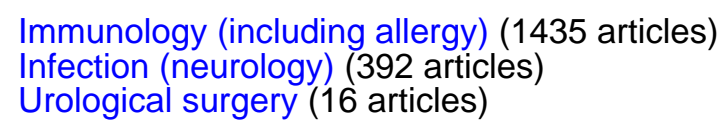

Notes

To request permissions go to:

http://group.bmj.com/group/rights-licensing/permissions

To order reprints go to:

http://journals.bmj.com/cgi/reprintform

To subscribe to BMJ go to:

http://group.bmj.com/subscribe/ 